\title{
KAJIAN DAMPAK KERUSAKAN LINGKUNGAN AKIBAT KEGIATAN PENAMBANGAN PASIR DI DESA KENINGAR DAERAH KAWASAN GUNUNG MERAPI
}

\author{
Yudhistira*, Wahyu Krisna Hidayat**, Agus Hadiyarto*** \\ *Program Studi Ilmu Ilmu Lingkungan, Program Pascasarjana Universitas Diponegoro Semarang \\ **Jurusan Teknik Geologi Fakultas Teknik Universitas Diponegoro Semarang \\ ***Jurusan Teknik Kimia Fakultas Teknik Universitas Diponegoro Semarang
}

\begin{abstract}
ABSTRAK
Pasir merupakan salah satu produk kegiatan Gunung Merapi yang, merupakan andalan pemerintah Kabupaten Magelang dalam meningkatkan Pendapatan Asli Daerah dan juga menyerap lapangan kerja. Selain mendatangkan manfaat penambangan pasir Merapi juga menimbulkan dampak lingkungan bagi daerah di lokasi penambangan dan juga bagi daerah di bawahnya Penelitian kajian dampak kerusakan lingkungan akibat kegiatan penambangan pasir bertujuan untuk mengkaji i) tingkat kerusakan lingkungan yang terjadi di lokasi penambangan pasir, ii) mengkaji dampak kerusakan lingkungan yang terjadi akibat penambangan pasir, iii) mengajukan usulan pengelolaan lokasi penambangan pasir. Penelitian ini dilaksanakan di Desa Keningar kecamatan Dukun Kabupaten Magelang. Metode penelitian yang digunakan metode analisis kuantitatif. Untuk penghitungan tingkat erosi dilakukan dengan rumus USLE sedangkan aspek sosial melakukan wawancara dengan pertanyaan terstruktur yang didukung kuesioner terhadap responden untuk mengetahui pendapat tentang lingkungan sekitar. Selanjutnya dalam rangka menentukan strategi dan kebijakan dalam penyusunan pengelolaan lingkungan penambangan pasir dilakukan analisa SWOT.Hasil penelitian menunjukkan tingkat erosi di lokasi penambangan pasir adalah moderat dan ringan dan menimbulkan dampak fisik lingkungan seperti tanah longsor, berkurangnya debit air permukaan (mata air), tingginya lalu lintas kendaraan membuat mudah rusaknya jalan, polusi udara, dan dampak sosial ekonomi. Dampak sosial ekonomi penyerapan tenaga kerja karena sebagian masyarakat bekerja menjadi tenaga kerja di penambangan pasir, adanya pemasukan bagi pemilik tanah yang dijual atau disewakan untuk diambil pasirnya dengan harga tinggi, banyaknya pendatang yang ikut menambang sehingga dapat menimbulkan konflik, adanya ketakutan sebagian masyarakat karena penambangan pasir yang berpotensi longsor.Berdasarkan analisis SWOT maka langkah-langkah yang perlu dilakukan untuk menghindari dampak lingkungan adalah dengan memanfaatkan teknologi konservasi lahan dan penegakan hukum melalui peraturan perundangan yang jelas, transparan dan akuntabel serta pelibatan peran aktif masyarakat.
\end{abstract}

Kata Kunci: Penambangan, pasir, alat berat, erosi, kerusakan, Keningar

\section{PENDAHULUAN}

Industri pertambangan merupakan salah satu industri yang diandalkan pemerintah Indonesia untuk mendatangkan devisa. Selain mendatangkan devisa industri pertambangan juga menyedot lapangan kerja dan bagi Kabupaten dan Kota merupakan sumber Pendapatan Asli Daerah (PAD).

Industri pertambangan selain mendatangkan devisa dan menyedot lapangan kerja juga rawan terhadap pengrusakan lingkungan. Banyak kegiatan penambangan yang mengundang sorotan masyarakat sekitarnya karena pengrusakan lingkungan, apalagi penambangan tanpa izin yang selain merusak lingkungan juga membahayakan jiwa penambang karena keterbatasan pengetahuan si penambang dan juga karena tidak adanya pengawasan dari dinas instansi terkait.

Menurut Undang-Undang Nomor 23 tahun 1997 tentang pengelolaan lingkungan, pengrusakan lingkungan adalah tindakan yang menimbulkan perubahan langsung/ tidak langsung terhadap sifat fisik dan atau hayatinya yang mengakibatkan lingkungan 
Yudhistira, Wahyu Krisna Hidayat, Agus Hadiyarto 2011. KAJIAN DAMPAK KERUSAKAN LINGKUNGAN AKIBAT KEGIATAN PENAMBANGAN PASIR DI DESA KENINGAR DAERAH KAWASAN GUNUNG MERAPI, . Jurnal Ilmu Lingkungan, Vol 9 (2): 76-84.

http://ejournal.undip.ac.id/index.php/ilmulingkungan

hidup tidak dapat berfungsi lagi dalam menunjang pembangunan berkelanjutan.

Salah satu indikator kerusakan lingkungan adalah erosi. Erosi adalah proses berpindahnya tanah atau batuan dari satu tempat yang lebih tinggi ke tempat yang lebih rendah akibat dorongan air, angin, atau gaya gravitasi. Proses tersebut melalui tiga tahapan, yaitu pelepasan, pengangkutan atau pergerakan, dan pengendapan.

Bahaya erosi banyak terjadi di daerahdaerah lahan kering terutama yang memiliki kemiringan lereng sekitar $15 \%$ atau lebih . Keadaan ini sebagai akibat dari pengelolaan tanah dan air yang keliru, tidak mengikuti kaidah-kaidah konservasi tanah dan air dan tanah. Menurut Soule dan Piper 1992, (dalam Yakin A, 2004) erosi mempunyai dampak negatif terhadap usaha pertanian/ perkebunan maupun diluar pertanian. Dampak utama erosi terhadap pertanian adalah kehilangan lapisan atas tanah yang subur, berkurangnya kedalaman lahan, kehilangan kelembapan tanah dan kehilangan kemampuan lahan untuk menghasilkan tanaman yang menguntungkan.

Secara keseluruhan terdapat lima faktor yang menyebabkan dan mempengaruhi besarnya laju erosi yaitu iklim, tanah,

topografi vegetasi penutup tanah dan kegiatan manusia. Faktor iklim yang paling menentukan adalah hujan yang dinyatakan dengan nilai erosivitas hujan. Besar kecilnya laju erosi banyak tergantung kepada sifat-sifat tanah yang dinyatakan sebagai faktor erodibilitas tanah yaitu kepekaan tanah terhadap erosi.

\section{METODE PENELITIAN}

Penelitian dilakukan untuk mengkaji tingkat kerusakan lingkungan yang terjadi dilokasi penambangan pasir dan dampak lingkungan akibat kegiatan penambangan pasir bagi masyarakat Tahapan penelitian dimulai dari studi pustaka, pengumpulan data sekunder, penelitian lapangan untuk mengambil sample, penelitian laboratorium untuk mengamati variabel yang diteliti pengolahan data dan pembahasan. Teknik Pengambilan sample dilakukan dengan pertimbangan tertentu (Purposive Sampling Metode).

\section{Lokasi penelitian}

Penelitian lapangan dilakukan di lokasi penambangan pasir CV Mitra Karya Desa Keningar Kecamatan Dukun Kabupaten Magelang. Penelitian laboratorium untuk mengkaji Tingkat Bahaya Erosi di laboratorium Mekanika Tanah Fakultas Teknik Universitas Diponegoro.

\section{Jenis dan Sumber Data Penelitian}

Jenis data yang digunakan dalam analisis berupa data primer yang diperoleh dari lapangan melalui wawancara dan oberservasi di lapangan untuk mengetahui tingkat dan dampak kerusakan lingkungan di lokasi penambangan pasir dan daerah sekitarnya. Data sekunder berupa pustaka, laporan, peta peta dari instansi terkait yang meliputi Kantor Pertambangan, Dinas Lingkungan Hidup, Dinas Pertanian, Badan Pusat Statistik Bappeda Kabupaten Magelang

\section{Metode Penghitungan Tingkat Erosi}

Untuk mengetahui tingkat kerusakan lahan yang terjadi yang salah satu indikatornya adalah tingkat bahaya erosi yang terjadi . Penentuan tingkat bahaya erosi dapat dihitung dengan menggunakan rumus (USLE) Wischmeier, et al (1965) dalam Suripin (2002)

$$
\mathrm{E}=\mathrm{RKLSCP}
$$

$\mathrm{E}=$ rata -rata erosi tanah tahunan (ton/ha);

$\mathrm{R}=$ Indek erosivitas hujan ;

$\mathrm{K}=$ Faktor erodibilitas tanah, yaitu kecepatan erosi per indeks erosi hujan sutu tanah dari petak percobaan standaryaitu petak percobaan yang panjangnya 22,1 meter yang terletak padadreng dengan kemiringan $9 \%$ dan tanpa tanaman

$\mathrm{L}=$ Faktor panjang lereng untuk menghitung erosi dibandingkan dengan lereng yang panjangnya 22,1 meter yang terletak pada lereng dengan kemiringan $9 \%$ dan tanpa tanaman

$\mathrm{S}=$ Faktor kemiringan lereng yaitu perbandingan antara besarnya erosi yang terjadi pada suatu bidang tanah dengan kecuraman tetentu, terhadap besarnya erosi pada tanah dengan kemiringan lereng $9 \%$ dengan kondisi identik 


\section{Faktor Erosivitas Hujan}

Faktor erosivitas hujan, $\mathrm{R}$ didevinisikan sebagai jumlah satuan indeks erosi hujan dalam setahun. Nilai $\mathrm{R}$ yang merupakan daya rusak hujan, dapat ditentukan dengan persamaan yang dilaporkan oleh Wischmeier, 1959 (dalam Renard, et al., 1996) sebagai berikut :

$$
\mathrm{EI}_{30}=\mathrm{E}\left(\mathrm{I}_{30} \times 10^{-2}\right)
$$

Di mana EI 30 adalah interaksi energi dengan intensitas maksimum, merupakan hasil perkalian energi hujan $\quad(\mathrm{E}=\mathrm{Kj} /$ ha-mm) dan intensitas maksimum 30 menit.

Validitas dari persamaan tersebut diatas untuk daerah tropis diragukan karena curah hujan biasanya sangat tinggi. Disamping itu, bahwa tidak semua tempat di negara -negara berkembang seperti Indonesia dioperasikan alat penakar hujan otomatis, maka telah dicoba mendapatkan metode lain untuk menentukan nilai $\mathrm{EI}_{30}$ dengan menggunakan data hujan yang tersedia. Lenvain, 1975 ( dalam Suripin 2002 ) mendapatkan hubungan antara $\mathrm{EI}_{30}$ dengan curah hujan tahunan (R) sebagai berikut $\mathrm{EI}_{30}=2,34 \mathrm{R}^{1,98}$

\section{Faktor Erodibilitas Tanah (K)}

Erodibilitas tanah atau faktor kepekaan erosi tanah yang merupakan daya tahan tanah baik terhadap penglepasan dan pengangkutan, terutama tergantung pada sifat-sifat tanah, seperti tekstur, stabilitas agregat, kekuatan geser, kapasitas infiltrasi ,kandungan bahan organik dan kimiawi. Disamping itu juga tergantung pada posisi topografi, kemiringan lereng dan gangguan oleh manusia. Faktor yang mempunyai pengaruh besar terhadap variasi erodibilitas tanah adalah suhu tanah, tekstur tanah dan kelengasan tanah.

Menurut Suripin (2002) untuk menentukan faktor Erodibilitas Tanah (K) dapat diperkirakan dengan monografi yang dikembangkan oleh Wischmeier, et al (1971) sebagaimana diperlihatkan dengan mempergunakan persamaan ,

$$
\begin{gathered}
\mathrm{K}=\left\{\left\{2,713 \times 10(12-0) \mathrm{M}^{1,14}+3,25(\mathrm{~S}-2)+\right.\right. \\
\left.2,5 \frac{(p-3)}{100}\right\}
\end{gathered}
$$

Dimana

$$
\begin{array}{lll}
\mathrm{M} & = & \text { Persentase pasir sangat } \\
\mathrm{O} & = & \text { halus dan debu } \\
\mathrm{S} & = & \text { Persentase bahan organik } \\
\mathrm{P} & = & \text { Kode struktur tanah } \\
& \text { Klas permeabelitas tanah }
\end{array}
$$

\section{Lereng \\ Faktor Panjang dan Kemiringan}

Faktor LS, kombinasi antara faktor panjang lereng (L) dan kemiringan lereng (S) merupakan nisbah besarnya erosi dari suatu lereng dengan panjang kemiringan tertentu terhadap besarnya erosi dan plot lahan dengan panjang 22,13 m dan kemiringan 9\%. Nilai LS untuk sembarang panjang lereng dapat dihitung dengan persamaan yang disampaikan oleh Wischmeier dan Smith, 1978 (dalam Morgan 1988) sebagai berikut

0,0138)

$$
\mathrm{LS}=\left[\frac{L}{22}\right]^{\mathrm{z}}\left(0,00138 \mathrm{~S}^{2}+0,00965 \mathrm{~S}+\right.
$$

Dimana L

$$
\begin{aligned}
& \mathrm{L}=\text { Panjang Lereng }(\mathrm{m}) \\
& \mathrm{S}=\text { Kemiringan lereng } \\
& \mathrm{Z}=(\%) \text { Konstanta }
\end{aligned}
$$

\section{Tingkat Bahaya Erosi}

Adapun penetuan kategori hasil perhitungan tingkat bahaya erosi pada satuan unit analisis dapat ditentukan dengan memasukkan pada klasifikasi pada Tabel 1 . sebagai berikut :

Tabel 1. Klasifikasi Tingkat Bahaya Erosi

\begin{tabular}{|c|c|c|}
\hline No & $\begin{array}{c}\text { Tingkat Bahaya } \\
\text { Erosi } \\
\text { (ton/ha/tahun) }\end{array}$ & Kategori \\
\hline 1. & $<15$ & Normal \\
2. & $15-60$ & Eropsi \\
3. & $60-180$ & Ringan \\
4. & $180-480$ & Moderat \\
5 & 480 & Berat \\
& & Sangat \\
& & Berat \\
\hline
\end{tabular}

Sumber : Keputusan Ditjen Reboisasi Dan Rehabilitas Departemen Kehutanan No.041/Kpts/V/1998

\section{Kewajiban Rehabilitasi Lahan}

Reklamasi Lahan Pasca Penambangan adalah suatu upaya pemanfaatan lahan pasca penambangan melalui rona perbaikan lingkungan fisik terutama pada bentang lahan yang telah dirusak. Upaya ini dilakukan untuk 
mengembalikan secara ekologis atau difungsikan menurut rencana peruntukannya dengan melihat konsep tata ruang dan kewilayahan secara ekologis. Kewajiban reklamasi lahan bisa dilakukan oleh pengusaha secara langsung mereklamasi lahan atau memberikan sejumlah uang sebagai jaminan akan melakukan reklamasi Berdasarkan data dari Departemen Energi dan Sumberdaya Mineral pada Tahun 2005 terdapat 186 perusahaan tambang yang masih aktif dengan total luas areal sekitar 57.703 ha dan hanya 20.086 ha yang telah direklamasi oleh para perusahaan yang memperoleh kontrak pada lahan tersebut. Sebagian lahan tersebut dikembalikan kepada petani untuk diusahakan kembali menjadi lahan pertanian. Sebagian pengusaha tidak mereklamasi lahan dan meninggalkan begitu saja.

Kewajiban pasca tambang yang bersifat fisik mempunyai dimensi ekonomi dan sosial yang sangat tinggi dan berpotensi menimbulkan konflik pada masyarakat dengan pemerintah dan juga usaha pertambangan. Oleh karena itu pengelolaan pasca tambang bukan merupakan masalah fisik, tetapi merupakan political will pemerintah untuk meregulasi secara benar dengan memperhatikan kaidah lingkungan. Kemudian mengimplementasikannya dengan mengedepankan kepentingan masyarakat lokal dan mengacu kepada falfasah ekonomi dan sosial serta akuntabilitas yang dapat dipercaya.

\section{Metode Analisis}

Berdasarkan data primer dan sekunder yang diperoleh maka selanjutnya dianalisis dengan menggunakan pendekatan analisis kuantitatif. Untuk penghitungan tingkat erosi dilakukan dengan rumus USLE sedangkan aspek sosial melakukan wawancara dengan pertanyaan terstruktur melalui kuisioner terhadap responden untuk mengetahui pendapat tentang lingkungan sekitarnya. Hal ini dilakukan dengan melihat persentase kecenderungan jawaban dari responden tersebut, yaitu

Jawaban responden $\times 100 \%=$ simpulan responden

Total responden.

\section{HASIL DAN PEMBAHASAN}

Berdasarkan klasifikasi Tingkat Bahaya Erosi menurut Ditjen Reboisasi Dan Rehabilitasi Departemen kehutanan No.041/Kpts/V/1998 maka nilai TBE yang diperoleh masuk dalam kategori moderat dan ringan. Hal ini harus menjadi pertimbangan dan pemikiran karena besarnya erosi yang terjadi berakibat dampak yang diakibatkan dari tingginya erosi terhadap lingkungan setempat maupun lingkungan di daerah bawah.

Perkiraan dampak lingkungan dengan adanya erosi di lokasi penambangan pasir desa Keningar Kawasan Gunung Merapi antara lain sebagai berikut

\section{Potensi Terjadinya Longsor}

Daerah penambangan pasir Desa Keningar kawasan Gunung Merapi merupakan daerah dengan potensi bahaya gerakan tanah (longsor) Daerah dengan tingkat bahaya erosi yang sangat tinggi menandakan tidak adanya tindakan konservasi lahan yang menyebabkan lahan mudah longsor sebagaimana terlihat pada dibawah ini

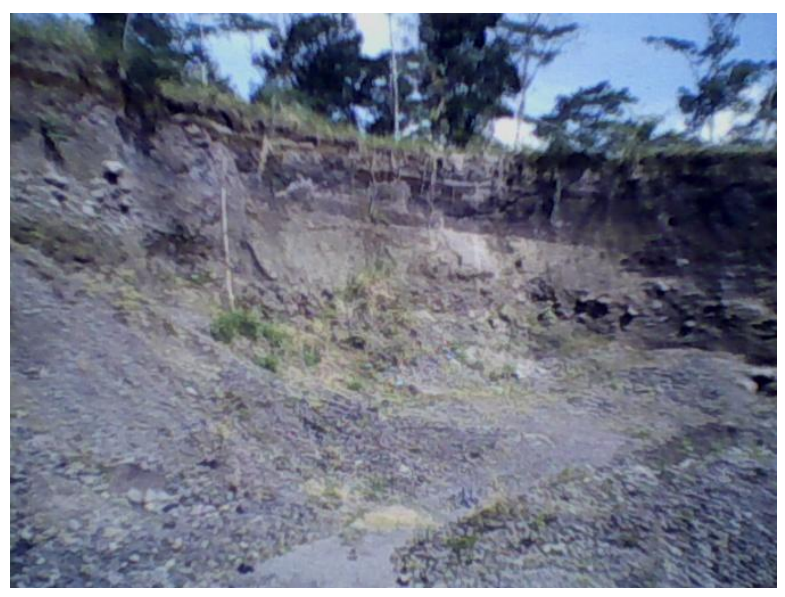

Gambar 1. Daerah Yang Berpotensi Terjadinya Longsor

Potensi terjadinya longsor jelas sangat berbah aya baik bagi penambang maupun masyarakat yang berada di sekitarnya. Banyak dari pemilik tanah di sekitar lokasi penambangan karena takut terkena longsor terpaksa menjual tanahnya.

\section{Berkurangnya Ketersediaan Air}

Daerah desa Keningar merupakan daerah tangkapan air bagi daerah dibawahnya. Dengan adanya lokasi penambangan pasir yang tidak 
mengindahkan konservasi tanah dan lahan dibuktikan dengan tingginya tingkat bahaya erosi yang terjadi menyebabkan besarnya air larian pada permukaan tanah sehingga kemampuan lahan untuk menampung air berkurang.

Hal ini dikeluhkan oleh warga yang mengaku air yang ada di kolam dan mata air menyusut, padahal air sangat dibutuhkan warga yang memanfaatkannya untuk keperluan sehari-hari.

\section{Perubahan Struktur Tanah}

Tingginya erosi yang terjadi di lokasi penambangan pasir akan menyebabkan hanyutnya partikel-partikel tanah dan sangat berpengaruh terhadap struktur tanah. Struktur tanah remah akan berubah menjadi struktur polyder atau terlepas.

Struktur tanah seperti ini menyebabkan rendahnya produktivitas hasil pertanian karena lahan tidak mengandung koloit tanah. Koloit tanah berfungsi sebagai perekat partikel-partikel tanah mendorong peningkatan stabilitas struktur tanah.

\section{Penurunan Kapasitas Infiltrasi dan Penyerapan Air Tanah}

Infiltrasi adalah peristiwa masuknya air tanah melalui permukaan tanah secara vertikal (Suripin, 2002). Sedangkan banyaknya air yang masuk melalui permukaan tanah persatuan waktu dikenal sebagai laju infiltrasi. Nilai laju infiltrasi sangat tergantung pada kapasitas infiltrasi, yaitu kemampuan tanah untuk melewati permukaan tanah secara vertical.

Rusaknya struktur tanah oleh erosi di daerah lokasi penambangan pasir di desa Keningar, akan menyebabkan mengecilnya pori-pori tanah, sehingga kapasitas infiltrasi menurun, dan aliran permukaan menjadi lancar. Hal ini dapat menyebabkan banjir dan longsor.

\section{Hilangnya Bahan Organik Tanah}

Penambangan pasir di desa Keningar yang tidak mengindahkan konservasi tanah dan lahan, akan menyebabkan erosi yang di ikuti hilangnya bahan organik tanah dan pemadatan tanah.

Hal ini menyebabkan berkurangnya air permukaan atau air hujan yang masuk ke dalam tanah. Akibatnya hujan yang jatuh dengan mudah terakumulasi dipermukaan. Kehilangan unsur hara karena adanya erosi di lokasi penambangan pasir desa Keningar, akan menurunkan produktivitas lahan. Hal ini membahayakan bagi lingkungan di desa Keningar maupun desa sekitarnya.

\section{Analisis Pengetahuan Masyarakat Tentang Lingkungan Hidup \\ Berdasarkan hasil penelitian tentang} responsi masyarakat serta persepsi masyarakat terhadap lingkungan, dapat maka dapat diketahui bahwa sebagian besar masyarakat paham mengenai lingkungan hidup secara umumnya dan juga paham mengenai pentingnya lingkungan hidup yang terpelihara secara lestari.

Adanya persepsi pengetahuan tentang lingkungan hidup tersebut dikarenakan masyarakat pedesaan akrab dengan lingkungannya terutama karena kebutuhan mereka akan lahan sebagai sumber kehidupan mereka yang sebagian besar petani/ buruh tani. Ironisnya eksploitasi sumberdaya alam tanpa dibarengi dengan pelestariannya akan menyebabkan rusaknya lingkungan sekitarnya. Sehingga persoalan lingkungan yang sangat mengganggu kelestarian alam yang berbias menjadi keresahan warga masyarakat sekitarnya.

\section{Persepsi Masyarakat Tentang Penambangan Pasir.}

Pengetahuan masyarakat secara umum tentang kegiatan penambangan pasir bahwa mereka dapat menerima penambangan pasir karena merupakan mata pencaharian atau pekerjaan bagi masyarakat penambang. Mereka melihat bahwa penambangan pasir memberikan manfaat sebagai pekerjaan pokok atau pekerjaan sampingan bagi masyarakat untuk memenuhi kebutuhan sehari-hari. Pekerjaan tersebut memberikan hasil setiap hari bagi penambang pasir guna memenuhi kebutuhan hidup sehari hari.

Kegiatan penambangan pasir selain memberikan manfaat langsung dari aktifitas penambangan juga membuka peluang kerja bagi buruh baik sebagai tukang coker, jaga malam pencatat angkutan material pasir serta berdagang makanan. Peyerapan tenaga kerja yang paling banyak hádala tukang coker atau buruh perata pasir. Besarnya upah buruh coker Rp 10.000,- sampai dengan Rp. 12.000,- per 
Yudhistira, Wahyu Krisna Hidayat, Agus Hadiyarto 2011. KAJIAN DAMPAK KERUSAKAN LINGKUNGAN AKIBAT KEGIATAN PENAMBANGAN PASIR DI DESA KENINGAR DAERAH KAWASAN GUNUNG MERAPI, . Jurnal Ilmu Lingkungan, Vol 9 (2): 76-84.

http://ejournal.undip.ac.id/index.php/ilmulingkungan

truk dan setiap orang dapat memperoleh giliran $2-3$ kali jika bekerja sebagai tukang coker saja. Sebagian penduduk ada yang bekerja sambilan sebagai tukang coker sepulang bekerja sebagai petani atau buruh tani. Tetapi secara umum kebanyakan profesi tukang coker ditangani kelompok pemuda.

\section{Dampak Lingkungan Kegiatan Penambangan Pasir}

Penambangan Pasir tidak hanya memberikan keuntungan dan manfaat tetapi juga menimbulkan permasalahan. Kegiatan penambangan pasir yang menggunakan alat berat yang berfungsi untuk mengeruk material yang berada di dataran maupun di dinding tebing menimbulkan permasalahan ekologis dan sosial bagi lingkungan sekitar. Dampak lingkungan dari kegiatan penambangan pasir di Desa Keningar di bedakan menjadi dampak fisik dan dampak sosial ekonomi.

\section{Dampak Fisik Lingkungan}

Dampak fisik lingkungan dengan adanya kegiatan penambangan pasir di Desa Keningar adalah sebagai berikut:

1. Tingginya tingkat erosi di daerah penambangan pasir dan juga didaerah sekitarnya.

2. Adanya tebing-tebing bukit yang rawan longsor karena penambangan yang tidak memakai sistem berteras sehinggaa sudut lereng menjadi terjal dan mudah longsor.

3. Berkurangnya debit air permukaan/ mata air

4. Tingginya lalu lintas kendaraan di jalan desa membuat mudah rusaknya jalan.

5. Terjadinya polusi udara.

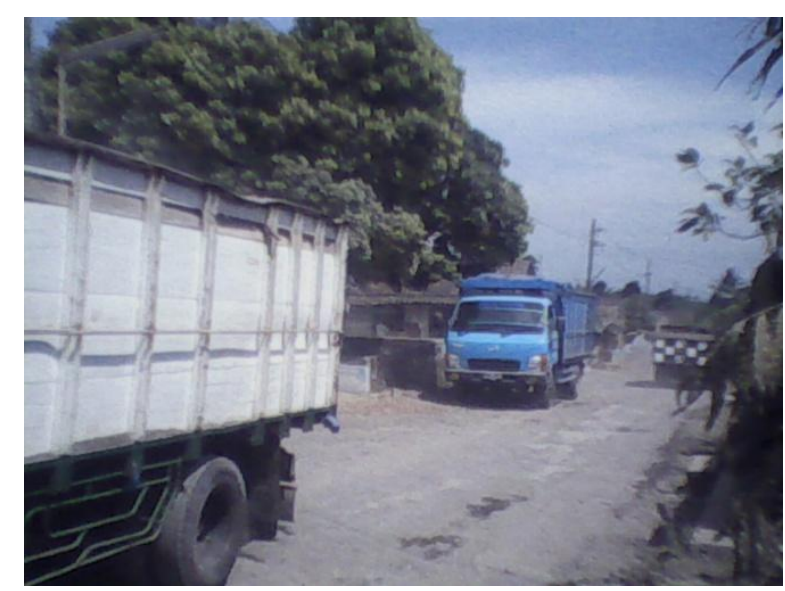

Gambar 2. Tingginya Lalu Lintas Kendaraan Membuat Mudah Rusaknya Jalan

\section{Dampak Sosial Ekonomi Masyarakat}

Berdasarkan wawancara dengan beberapa narasumber dapat diketahui dampak sosial ekonomi yang terjadi dengan adanya kegiatan penambangan pasir

1. Pengurangan jumlah pengangguran karena sebagian masyarakat bekerja menjadi tenaga kerja di penambangan pasir, baik sebagai pengawas, buruh tambang, penjual makanan dan minuman .

2. Adanya pemasukan bagi pemilik tanah yang dijual atau disewakan untuk diambil pasirnya dengan harga tinggi. Tanah yang semula tidak menghasilkan menjadi bermanfaat karena dipakai untuk penambangan pasir.

3. Banyaknya pendatang yang ikut menambang sehingga dapat menimbulkan konflik.

4. Adanya ketakutan sebagian masyarakat karena penambangan pasir yang berpotensi longsor sehingga sewaktu-waktu bisa mengenai lahan dan pemukiman mereka, apalagi bila turun hujan .

\section{Analisis Kebijakan Pertambangan Yang Telah Dilakukan Pemerintah Kabupaten Magelang}

Pemerintah Kabupaten Magelang menetapkan Perda Nomor 1 Tahun 2008 tentang Usaha Pertambangan menggantikan Perda Nomor 23 Tahun 2001 tentang Izin Usaha Pertambangan.

Selain itu pada tanggal 24 Agustus 2004 Pemerintah kabupaten Magelang mengeluarkan dua kebijakan yaitu Penataan dan Penertiban Kegiatan Pertambangan dan Pengaturan Rute dan Tonase Angkutan Bahan Galian Golongan C di Kawasan Merapi Kabupaten Magelang

Sejumlah peraturan perundangundangan tersebut sudah cukup baik dan memadai sebagai landasan dalam rangka pengelolaan pertambangan pasir yang berwawasan lingkungan. akan tetapi dalam penerapannya sangat sulit untuk dapat dilaksanakan dengan baik dikarenakan banyaknya tantangan dan kendala yang menghambat konsekuensi pelaksanaan aturan kebijakan. Misalnya dalam penerapan aturan perizinan penambangan pasir pada saat penelitian hanya satu perusahaan yang 
mempunyai SIPD (Surat Izin Pertambangan Daerah) atas nama CV Mitra Karya sedangkan yang lainnya adalah penambangan dengan tanpa disertai perizinan

Permasalahan mendasar dalam pengaturan regulasi penambangan pasir dilihat dari sisi pemegang kebijakan yaitu pemerintah dapat ditinjau dari dua sudut pandang, yaitu sisi internal pemerintah daerah itu sendiri serta sisi eksternal pemerintah daerah. Permasalahan internal yang terjadi diantaranya adalah antar kelembagaan pemerintah kurang koordinasi, aparatur pemerintah kurang profesional, anggaran operasional terbatas dan sarana dan prasarana operasional yang terbatas. Permasalahan internal tersebut berakibat kurang optimalnya pemerintah dalam melaksanakan tugas pokok dan fungsinya menerapkan peraturan yang berlaku.

Permasalahan eksternal berasal dari luar lingkup pemerintah daerah, misalnya permasalahan yang berasal dari masyarakat, penambang, pengusaha serta organisasi atau lembaga swadaya masyarakat. Permasalahan eksternal ini dapat menjadi tantangan bagi pemerintah dalam pengelolaan penambangan pasir, diantaranya adalah kesadaran masyarakat yang kurang terhadap lingkungan hidup, tuntutan menghadapi kehidupan dari masyarakat, kurangnya penelitian sebagai sumber informasi dalam mengambil kebijakan pemerintah dan kritikan dari lembaga swadaya masyarakat yang pada umumnya kurang respek terhadap usaha pertambangan. Oleh karena itu kontrol secara terus menerus dari pemerintah terhadap setiap kegiatan penambangan pasir dan batu perlu diupayakan. Kegiatan sosialisasi peraturan perundang-undangan disertai pengawasan dan pengendalian bersama antar berbagai pihak yang terkait diharapkan dapat terpadu dan berkelanjutan

Strategi pengaturan kebijakan pemerintah terhadap penambangan pasir yang utama adalah penerapan peraturan perundangundangan yang berlaku secara konsekuen dan memberdayakan masyarakat. Tugas pokok dan fungsi lembaga teknis yang bertanggung jawab dalam hal pertambangan dilaksanakan secara profesional, transparan dan akuntabel. Pada prinsipnya pengaturan kebijakan pemerintah dalam penambangan pasir adalah mengupayakan suatu sistem pengelolaan penambangan yang berwawasan lingkungan dan menjaga keseimbangan material yang terambil di bagian hulu sampai hilir agar tidak merusak ekosistem Gunung Merapi

\section{KESIMPULAN DAN REKOMENDASI}

Kesimpulan yang diperoleh dari penelitian Kajian Dampak Lingkungan Akibat Kegiatan Penambangan Pasir Di Desa Keningar Daerah Kawasan Gunung Merapi Kabupaten Magelang adalah sebagai berikut

1. Berdasarkan Rumus USLE dapat diperoleh dugaan erosi yang terjadi pada lokasi penambangan pasir Desa keningar Kecamatan Dukun Kabupaten Magelang adalah Total dugaan erosi yang terjadi $=$ $7830401,90+935674,09=8766076$ ton $/$ tahun. Tingkat Bahaya Erosi berdasarkan Keputusan Ditjen Reboisasi Dan Rehabilitasi Departemen Kehutanan No.041/Kpts/V/1998 adalah moderat dan ringan Faktor penyebab tingginya tingkat bahaya erosi adalah karena penambangan pasir yang tidak megindahkan konservasi tanah dan lahan serta faktor geografis dan geologis daerah penelitian.

2. Kegiatan penambangan pasir di Desa Keningar Kecamatan Dukun Kabupaten Magelang menimbulkan dampak terhadap lingkungan yaitu dampak fisik dan dampak sosial ekonomi. Dampak fisik lingkungan yaitu adanya tebing-tebing bukit yang rawan longsor, kurangnya debit air permukaan/ mataair, rusaknya jalan.polusi udara. Dampak sosial ekonomi penyerapan tenaga kerja karena sebagian masyarakat bekerja menjadi tenaga kerja di penambangan pasir, adanya pemasukan bagi pemilik tanah yang dijual atau disewakan untuk diambil pasirnya dengan harga tinggi, banyaknya pendatang yang ikut menambang sehingga dapat menimbulkan konflik. adanya ketakutan sebagian masyarakat karena penambangan pasir yang berpotensi longsor sehingga sewaktu-waktu bisa mengenai lahan dan pemukiman mereka, apalagi bila turun hujan.

3. Model perencanaan pengelolaan lingkungan di lokasi penambangan pasir 
Yudhistira, Wahyu Krisna Hidayat, Agus Hadiyarto 2011. KAJIAN DAMPAK KERUSAKAN LINGKUNGAN AKIBAT KEGIATAN PENAMBANGAN PASIR DI DESA KENINGAR DAERAH KAWASAN GUNUNG MERAPI, . Jurnal Ilmu Lingkungan, Vol 9 (2): 76-84.

http://ejournal.undip.ac.id/index.php/ilmulingkungan

Desa Keningar Kecamatan Dukun Kabupaten Magelang disusun berdasarkan metode tujuh langkah perencanaan dengan tujuan untuk mengatasi persoalan yang ada Berdasarkan analisis SWOT maka diperoleh lima alternatif kebijakan. Selanjutnya diambil keputusan dengan prinsip pengembangan masyarakat bersifat partisipatif dan koloboratif, transparansi dalam operasional pelaksanaan kebijakan dan peraturan perundang-undangan, akuntabilitas dalam peraturan penambangan bagi semua stakeholders, pengembangan masyarakat merupakan bagian dari responsibilitas. Langkah-langkah pelaksanaan pengelolaan penambangan pasir yang berwawasan lingkungan secara garis besar dapat dibagi menjadi beberapa kegiatan yaitu penentuan lokasi penambangan pasir, reklamasi/ rehabilitasi lahan pasca penambangan, pengendalian erosi. Tujuan akhir dari penambangan adalah mengatasi kerusakan lingkungan yang ada, mengendalikan laju erosi serta meningkatkan kesejahteraan masyarakat.

\section{Rekomendasi}

Dari kesimpulan di atas perlu dikemukakan beberapa saran yang berkaitan dengan hasil penelitian ini, yaitu:

1. Membentuk lembaga khusus yang menangani pengelolaan kegiatan penambangan di Desa Keningar kawasan Gunung Merapi.

2. Pemerintah Kabupaten Magelang perlu meningkatkan koordinasi antar anggota tim penataan dan penindakan pelanggaran penambangan sehingga pengawasan lebih efektif.

3. Penyusunan zonasi pertambangan yang memuat lokasi-lokasi yang dicadangkan dicadangkan untuk penambangan berdasarkan keberadaan deposit bahan tambang dan pertimbangan ekologis

4. Dugaan adanya laju erosi yang tinggi di lokasi penambangan pasir desa Keningar harus diperhatikan dan segera dilakukan tindakan pengendalian erosi sehingga kerusakan lingkungan yang terjadi tidak semakin meluas dan parah

5. Penggantian iuran reklamasi dalam bentuk jaminan reklamasi untuk penambang besar sehingga mereka mempunyai rasa tanggung jawab untuk melaksanakan penataan lahan pasca penambangan.

6. Pemberdayaan ekonomi masyarakat berdasarkan potensi lokal, sehingga ketergantungan terhadap sumber bahan tambang menjadi berkurang

\section{DAFTAR PUSTAKA}

As'ad, 2005., Pengelolaan Lingkungan pada Penambangan Rakyat (Studi Kasus Penambangan Intan Rakyat di Kecamatan Cempaka Kota Banjarbaru Propinsi Kalimantan Selatan)Tesis MIL UNDIP.

Asdak,C, 2004., Hidrologi dan Pegelolaan Daerah Aliran Sungai, Gadjah Mada University Press, Yogyakarta

Arsyad, S (1989)., Konservasi Tanah dan Air , IPB Bogor

Fitri Almaida, Boniska., 2008 Kajian Dampak Lingkungan Kegiatan Penambangan Bahan Galian Golongann C (Studi Kasus daerah Sendangmulyo) Tesis MIL UNDIP

Boothroyd, Peter, Looking Up at The Regional: Regional Issues from a Community Development Perspective. Vancouver, Canada : UBC school of Planning, 1991

Dinas Lingkungan Hidup Kabupaten Magelang., 2007, Status Lingkungan Hidup Daerah Kabupaten Magelang 2007, Pemerintah Kabupaten Magelang.

CV Mitra Karya., 2005 Dokumen UKL dan UPL Penambangan Bahan Galian Golongan C Desa Keningar Kecamatan Dukun Di Kabupaten Magelang

Hadi. S.P ., 2006, Resolusi Konflik Lingkungan, Badan penerbit UniversitasDiponegoro, Semarang.

Hardiyatmo,H.C.,2006, Penanganan Tanah Longsor dan Erosi, Edisi Pertama, Gajah Mada University Press, Yogyakarta.

Mantra.Ida Bagus 2004, Demografi Umum, Edisi 3, Pustaka Pelajar, Yogyakarta.

Nur Dyahwanti, Inarni., 2007, , Kajian Dampak Kerusakan Lingkungan Akibat 
Penambangan Pasir Di Daerah Gunung Sumbing (Studi Kasus Di Desa Kwadungan Gunung Kecamatan Kledung Kabupaten Temanggung Tesis MIL UNDIP

Ismail., 2007, Analisis Implementasi Kebijakan Pertambangan Bahan Galian Golongan C Di Kawasan Gunung Merapi Kabupaten Magelang,Tesis MIL UNDIP

Lahar Flood Control Project of Mt Merapi., 2001, Study on Supported Infrastructure Development for Sand Mining Management in Mt Merapi

Directorate General of Water Resources. Ministry of Settlements and Regional Infrastructure. Republic Indonesia

Magister Ilmu Lingkungan UNDIP.,2006 Buku Petunjuk Penulisan Tesis Mahasiswa

Moleong. LJ., 2002. Metode Penelitian Kualitatif. Edisi 16, Remaja Rosdakarya, Bandung

Morgan, R.P.C., 1988 Soil Erosion and Conservation, Longman Group, Hongkong

Nomor 27 Tahun 1980., Peraturan Pemerintah Tentang Penggolongan Bahan Galian

Nomor 23 Tahun 2001., Peraturan Daerah Kabupaten Magelang tentang Izin Usaha Pertambangan.

Nomor 1 Tahun 2008., Peraturan Daerah Kabupaten Magelang Tentang Usaha Pertambangan,

Nomor 8 Tahun 2006, Peraturan Bupati Magelang tentang Pembatasan Waktu Operasional Penambangan Bahan Galian Golongan C di Kabupaten Magelang,

Nomor 8 Tahun 2006 ,Peraturan Bupati Magelang tentang Pembatasan Daya Angkut (Tonase) Muatan Truk Angkutan Bahan Galian Golongan C di ruas Jalan Muntilan- Talun Kabupaten Magelang

P4N UGM., Proyek Penataan dan Pengaturan Usaha Pertambangan Kawasan Gunung Merapi TA 2000, Laporan Akhir. Universitas Gajah Mada Yogyakarta

Rahim, F., 1995, Sistem dan Alat Tambang, Akademi Teknik Pertambangan Nasional Banjarbaru.

Salim, A., 2006. Teori dan Paradigma Penelitian Sosial, Tiara Wacana, Yogyakarta

Singarimbun, M., 1982, Metode Penelitian Survei, LP3ES, Jakarta.

Sudibyo,J., 2002, Menuju Kegiatan Pengelolaan Pertambangan Bahan Galian Golongan C Berwawasan Lingkungan di Kawasan Gunung Merapi, Kabupaten Magelang, Tesis, ITB Bandung
Sudjarwo , 2001., Metodologi Penelitian Sosial , Mandar Maju, Bandung

Sutikno, Widiyanto., 2004 Potensi Sumberdaya Alam Gunung Merapi dan Pengelolaannya Untuk Mendukung Kehidupan Masyarakat Sekitar, Laporan Hasil Penelitian Hibah Bersaing X/3 Lembaga Penelitian Universitas Gadjah Mada, Yogyakarta

Sumaatmadja, N., 1988 Studi Geografi : Suatu Pendekatan dan Analisa Keruangan, Alumni Bandung

Soemarwoto., Otto., 2003, Analisis Mengenai Dampak Lingkungan, Gadjah Mada University Press, Yogyakarta

Suripin., 2002., Pelestarian Sumber daya Tanah dan Air, Andi Offset Yogyakarta.

Yakin,Addinul., 2004, Ekonomi Sumberdaya dan Lingkungan, Akademika Presindo,Jakarta 